\title{
Translating Connotative Meaning in Literary Texts at the University of Petra
}

\author{
Akram M. Beiruti \\ University of Petra \\ English Department/Tanslation \\ PO.Box 961422 \\ Amman 11196, Jordan \\ Tel: +962777482205 E-mail: akrambeiruti@yahoo.com
}

Received: 17-05-2013

doi:10.7575/aiac.ijalel.v.2n.5p.81
Published: 01-09-2013

\begin{abstract}
This article is primarily concerned with the investigation of the importance of connotation in translation. The four meanings normally discussed in semantics are denotation, connotation, reference and sense. Denotation is the frame of meaning, which is found in definitions given by dictionaries; while connotation is an additional shade of meaning added to the denotation of a word. Pragmatic meanings play an important role in the interpretation of a literary text. They need to be handled carefully by translators, and are likely not to survive the process of translation. Their meanings are fragile and often culture specific. They may also be highly personal associated with the author himself. In literary translation, meaning can only be accurate to a certain degree, since it is looking for the connotative as well as the denotative meanings. As such the successful translator is aware of the multiple meanings of the word. Whilst the translator has to cope with the different shades of word meanings, which are in non-literary translation, he can achieve anywhere near perfection. It worth mentioning that poetry is the hardest of all literary genres to translate, because it has some linguistic factors to account for (notably sound, rhyme and meter and connotation). Thus the importance of connotation is of utmost importance in translation. which translators have to be aware of.
\end{abstract}

URL: http://dx.doi.org/10.7575/aiac.ijalel.v.2n.5p.81

Keywords: connotation- denotation - translation - referential - poetry-sense

\section{Introduction}

The term 'connotation' was first used by J.S. Mill in 1843 in a slightly different sense from the one which is commonly used nowadays. In his System of Logie, Mill says : 'The word ' white' denotes all white things; as snow, paper, the foam of the sea, and so forth, and implies, or as it was termed by the schoolmen, connotes the attribute whiteness (Lyons 1977, p. 175). The definition states that individuals belonging to a class are the denotation of that class, whereas the property or properties which would entitle an individual to its connotation. To Mill 'connotation' is the signification of the property; 'denotation' is the signification of the thing. Nowadays \connotation 'is used in contrast to 'denotation' to refer to any additional meaning that an expression may acquire over and above its denotation or cognitive meaning. Ulmann (1962) believes that this distinction is related to Mill's distinguishing between the denotative function of proper names and the connotative value of common nouns. According to this reasoning names denote but do not refer to any property (attribute) of the individual, while common nouns connote or imply the attributes of the individual.

Connotative meaning is often linked with emotive meaning to be distinguished from the basic meaning which is the foundation of the truth conditional semantics. A proposition is judged true or false solely on the basis of its denotation. This trend reached its climax in the positivism of 1930s, which insisted that any expression that could not be verified in terms of true or false was emotive, not worthy of philosophical attention.

Denotation and connotation are also related to 'literal' and 'figurative' or metaphorical meaning. Beardsley writes:

The literal meaning of 'pig' is just its designation, the characteristics of having four legs, having a snout, and so forth. If you say, 'The animal in that pen is a pig', this statement can be literally true; an animal can have four legs. In this context, the connotations of 'pig' are not stressed. But if you say, 'That man over there is a pig, 'he has not four legs. Thus, if the statement is to be true at all, it is not the designation, but only the connotation, of 'pig' that is being ascribed to the man. In this case 'pig' is used metaphorically, and this metaphorical statement is (or may be, depending on the context) equal to a number of literal statements: he is greedy, he is gross, he is dirty, he is lazy, he is fat, (Beardsley, 1975. P. 196).

Thus Beardsley derives connotation from metaphorical meaning: pig: literal meaning: four legs. Pig: metaphorical meaning: connotation (a set of literal statements: he is lazy, he is dirty, etc. It is probably true that metaphorical meaning is more context dependent than literal meaning, but both of them must have a type of contextualization.

Empson's (1953p.48) second type ambiguity sheds some light on the confusion caused by connotation. In this type of ambiguity 'two or more meanings are resolved into one'. Empson points out that literature, especially poetry, requires the reader to foreground a set of meanings in a linguistic form; whereas in other texts only one meaning is foregrounded. "Connotation refers to the various meanings evoked by a certain use of an expression. This use of 
language is basic in literature. Denotation evokes only a single meaning (which is characteristic of scientific language). In Hjemalev's stratified model neither denotation nor connotation is the basic meaning: these are two different expression planes; they use different semiotic planes of expression.

In systemic functional theory various levels of contextualization are used to determine the denotation and connotation and discourse meaning of lexical items Using Beardsley's example, 'That man is a pig'. Thibault (1994, p. 709) suggests the following responses:

(a) Yes, he's disguising.

(b) Yes, he'd make a fine Christmas meal.

(c) He's the sort of actor who'd be better playing the fox.

(d) Are you crazy? He's a human being.se

In the lexical semantics adopted by some linguists, including Ullmann, Lyons and Beardsley, the meaning of a lexical item is determined only by one level, namely, the experiential or propositional level. However, this mono-level of analysis has been extended to include other levels, namely, the experiential or propositional level. However, this monolevel of analysis has been extended to include other levels, namely, interpersonal and textual. In the determination of the meaning of 'pig' in discourse semantics, responses (a) and (b) are explained on the nonsolidary is reconstrued; responses (c) and (d) use the solidary experiential meaning, in the former the meaning is explained by an alternative proposition, in the latter the logical basis of the experiential meaning is challenged (Thibault 1994, p. 709). In this argument, (a) and (b) foreground 'connotation' of 'pig'; (c) and (d) emphasizes 'denotation' of 'pig'.

\section{Types of connotative meaning}

Several approaches have been used to classify connotations into subtypes. Ullmann (1962, pp. 142-3) mentions nine aspects by which cognitive (connotations) synonyms may differ. They range from 'sensitive' to 'moral' forming a cline. Harvey et al. (1992, pp. 102-14) suggest six subclasses $\backslash$; attitudinal, associative, affective, reflective, collective, and allusive. Some of these have been adopted in this study, which distinguishes six kinds of connotation, and allusive connotation. These subtypes will be discussed in the present section; section 3 will relate these connotations to the process of translation; the main points of this article will be summarized in section 4.

\subsection{Sound connotation}

Sounds are often suggestive. In Antony's Oration (Julius Caesar III.2. 106-107) we read: 'O judgment, thou art fled to brutish beasts/ and men have lost their reason!' The sounds in 'brutish' suggest, through alliteration and assonance' Brutus', the main target of Antony's attack. Thus through a sound echo, Brutus is associated with 'brutish beasts' which lack human judgment, In classical Arabic literature there is a proverb, اصدق من قطاة, which Abu Nawas uses in his line:

(More truthful than a sand grouse which says 'qata': the name of the bird in Arabic). But probably the best Arabic example of connotative meaning based on sound suggestiveness, is the following, which occurs in Al-Aghani (VI, 7879). Hammad Al-Rawiya recites before the CaliphA1-Mansur a poem by Jarir, which has the

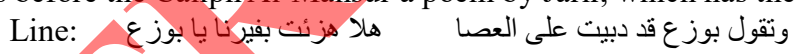

(And Bawza' says, you walk slowly with a stick, why don't make fun of others, O Bawza')

Al-Mansur: And what's Bawza'?

Hammad Al-Rawiya: The name of a woman, my Lord.

AL-Mansur: A woman called ' Bawza': I swear by God and His

messenger, Bawza' is none other than a ghul (monster),

This terrified me, in my dream last night. Guards take him out and give him a good beat.

Phonaesthetic effects may be achieved through rhyme, alliteration, assonance, onomatopoeia. Poets have always recognized the effectiveness of sound symbolism in evoking certain shades of emotive meaning.

2.2 Etymological connotation

Close reading involves careful attention to the origin of words and their meanings. This is especially true when one deals with texts that are several centuries old. Reading such texts requires interpretative efforts, a practice in hermeneutics. The best example of this trend in interpretation theory is After Babel by George Steiner (1975). Steiner begins chapter one of his book by citing Posthumus' rail against Iachimo in Act II of Cymbeline:

Is there no way for man to be, but women

Must be half -workers? We are all bastards,

And that most venerable man, which I

Did call my father, was I know not where

When I was stamp'd. Some coiner with his tools

Made me a counterfeit. Yet my mother seem'd

The Dian of that time; so doth my wife

The nonpareil of this. O Vengeance, Vengeneance.

Steiner I1975) comments on the four words 'stamp'd', 'coiner', 'tools', and 'counterfeit' saying that 'several currents of meaning and implications are interwoven '. He goes on to say that 'counterfeit' is 'to Steiner the meaning of adulteration and adultery would be characteristic of Shakespeare's total responsiveness to the field of relevant force and intimation in which words conduct their complex lives 1975, p. 3). He comments on 'tools' as having a gross 
sexual resonance. (Incidentally the same connotation is found in the equivalent Arabic word).

All these connotations that a word might have in previous centuries are relevant to our understanding of a text written before our time. Sometimes they are important even in modern texts. It may be interesting here to mention the word 'symposium'. Whenever, I hear or read this word my mind goes back to the symposium' of Plato. True, the meaning 'a drinking parity' has changed considerably, but it still retains some shades of its original signification. 'Any thorough reading of a text of the past of one's language and literature, 'says Steiner, 'is a manifold act of interpretation' $(1975, \mathrm{p}$. 16). This act of interpretation necessarily involves both the denotation and the connotation and the connection of a word.

\subsection{Referential connotation}

The referent of a word may have certain connotations besides it cognitive meaning. Thus 'nurse' normally refers to a female person who looks after the sick. The 'female' connotation of 'nurse' has persisted and resulted in coining the expression 'male nurse'; and there is still some oddness about 'he is a nurse' (Harvey, et al. 1992, pp. 103-04). The severe heat of summer in Arabia has attached pejorative connotation to the words 'heat', 'hot' and 'warm' in classical Arabic language and literature. Thus سخنت عينك (may your eye become hot) is a curse. The opposite terms 'cold' and 'cool', on the other hand, have a favourable sense, قرت عينك

(May your eye become cool or cold.)? Under the influence of translation from European languages, these terms have radically changed their connotations in modern Arabic, as illustrated by the expressions: إستقبال حار (literally: a hot reception: a warm reception) and إستقبال بارد (a cold reception).

Taboo words referring to various types of food, drink, body functions have repulsive connotations associated with the referent and are transferred to the designation. These referential meanings are culture specific: wine, and pork. For instance, they have unaccepted religious connotations in Moslem communities, but not in the West. The favourable or unfavourable colouring associated with the referent may be conventional, as in 'owl' which in Arabic is said to be a bird of ill omen, whereas in the West it connotes wisdom. Colours are usually associated with certain feelings: 'black' indicates sadness; white', purity; 'green', lack of experience, 'red', danger. All these symbolic meanings are arbitrary and may differ from culture to culture.

2.4 Collocational connotation

Contextual theories of meaning distinguish two kinds of context: the context of situation and linguistic context. Within linguistic context the notion of collocation, introduced by Firth (1957, p. 197). plays a prominent role. The meaning of a word is determined to a great extent by the other words with which it is habitually juxtaposed. Firth (1997, p. 197) says that 'one of the meanings of 'night' is its collocability with 'dark' and of dark' of course collocations with 'night'. Shakespeare uses 'nighted' with the connotation of 'black and sad', as in 'Good Hamlet, and cast that nighted colour off' (I. 2.68). Other examples of collocation are 'black and 'ink' in English, and 'black 'and 'tar' (أسود فار) in Arabic. 'Bread and butter' has been so frequently used that the two words have now become a unit and require a singular verb. Some words can collocate with a wide range of lexical items; 'nice' is one of these words, which can collocate almost with any word, e.g. a nice person, a nice pair of shoes, a nice party, etc. The word has almost lost its denotation. The adjective 'addled' and 'rancid', on the other hand, can collocate only with one or two words: 'addled' eggs, brain' and 'rancid butter'. 'A beautiful boy' is unusual, a 'beautiful girl' is normal; a 'handsome girl' is not often used; whereas a 'handsome boy' is quite usual. One often hesitates to use 'intercourse' because of its sexual connotation through the collocation 'sexual intercourse'

2.5 Reflected connotation

The vocabulary of a language is not merely a list of words; it consists of lexical items related through a number of structural relations including synonymy (pretty-beautiful), opposition (pretty-ugly), hyponymy (flower-rose), homonymy (bank-bank) and polysemy (head of a man -head of a department). These relations form the basis of additional suggestive meanings. Homonymy and polysemy are especially effective in evoking reflected meaning. The expressions 'the holy ghost' and 'the holy spirit' are synonymous, but they differ in their connotations (Harvey et al 1992, p. 105). In the 'holy ghost' the word 'ghost' evokes spook' and specter '; 'spirit' in 'the Holy Spirit' is associated with alcoholic drinks'. The connotation of 'drug' is different from that of 'medicine'. All meaning derived from puns is based on homonymy, as in the following example from Hamlet (I.2.64-71).

King. But now, my cousin Hamlet, and my son

How it is the clouds still hang on you?

Hamlet. Not so, my Lord. I am too much in the sun.

The homonymous (homophonic) 'son' and 'sun' add additional meaning to these items. The relations of contrast between 'cloud' and 'sun' add additional meaning to these items. The relation of contrast between 'cloud' and 'sun' should also be noted. All these shades of meaning form an integral part of the connotations of the word.

2.6 Allusive connotation

Texts help to construct other texts by hinting, which is the basis of allusive connotation. If we read, 'I know, madam, we're all a peninsula', the implied basis is John Donne 'a sermon, 'No man is an island entire of himself' The implied meaning here has a slight ironic 'island'. If someone complains that there are too many cooks, the hint is at the proverb 'too many cooks spoil the broth'. We read in Hamlet (III.1. 144-6).

Hamlet. You jig and amble, and you lisp. You nickname God's creatures and

Make your wantonness your ignorance. 
The allusion in 'you nickname God's creatures' is to the Book of Genesis I.9, where God commands Adam to give each creature a name. Hamlet's speech implies bitter criticism of Ophelia. In 1935 C. Day Lewis wrote an ironic poem:

Come live with me and be my love,

And we will all the pleasures prove

Of peace and plenty, bed and board,

That chance employment may afford.

The irony in these lines will be lost unless the reader is acquainted with Christopher Marlowe's pastoral poem written more than three centuries before 1600 :

Come live with me and be my love,

And we will all the pleasures prove

That valleys, groves, hills, and fields,

Woods or steepy mountain yields.

In modern linguistics this relation between one text and another is studied under intertextuality, which is the main source of allusive connotation.

\section{Connotative meaning and translation}

It is undoubtedly true that translating of a word or expression is easier than rendering its connotation into another language. Finding an English equivalent for the Arabic word جمل hardly poses a problem, for the animal camel is known to the English people; but the connotations raised by the word جمل and 'camel' are no doubt different. To an English man, 'camel' is the name of an exotic animal; an Arab, on the other hand, thinks of the camel as a friendly animal, which is commonly used in Arabic literature; it connotes, among other things, patience, faithfulness and even vindictiveness. All these connotations are absent from the English word camel. The translation of the word may result in some shift in the overall meaning of the source text. This is probably unavoidable; if we admit that all translation is based on approximation rather than on identity. More serious, however, is the problem raised by a clash between the connotations of the words in the source and the target texts. For example, alcoholic drinks, pork and many other words are likely to suggest different or even wrong views for the new reader, and hence pose serious problems for the translator.

A quick look at the six subtypes of connotation will show that some of them are mainly linguistic-sound, etymological, collocational, and reflected; the others are basically cultural - referential and associative. Connotations being either language specific or culture specific resist translation; it is rarely possible that connotations of a word match those of another word in a different language. It is easy to envisage the seriousness of this problem if we are aware that all literature depends on its power of suggestiveness - or its connotations. It is precisely this 'literariness' which is often left out in the process of translation, especially in poetry. The crucial question is how to compensate for this loss. Literary translators make use of supplementary notes whenever necessary. It should be noted however that not all the connotations of a word are relevant to the meaning of a text; some connotations are foregrounded, others are not. It is an important task of the translator to recognize which connotations are foregrounded and which are not. In the following lines from the Rime of the Ancient Mariner

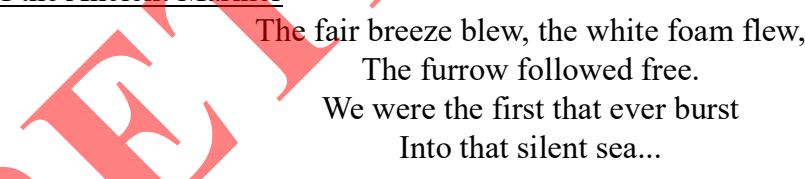

Coleridge uses alliteration and rhymes to give a vivid picture of the ship sailing on that lonely sea, the translator is required to render these sound effects into the new language. In one Arabic translation of Julius Caesar, the translator is partially successful in rendering 'brutish beasts' as ' البهائم والوحوش.'Alliteration is here weaker than the alliteration and assonance in the original.

Etymological connotations raise no less serious problems. For example, we read in The Merchant of Venice (I.3, 12931):

\section{Shylock. If thou wilt this money, lend it not}

As breed for barren metal of his friend,

The expression 'a breed for barren metal', which means 'interest', extends its roots into the Aristotelian doctrine which stated that money differed from living things in that it cannot breed. These Aristotelian connotations can only be rendered through an additional note. Here is another example from The Merry Wives of Windsor (I.3. 75-76), where the history of words proves highly suggestive:

Pistol. Shall I Sir Pandarus of Troy become?

And by my side wear steel?

Pistol is referring to the Greek soldier who shot an arrow in the Trojan War and broke the peace. From the name Panderus is derived from the verb 'pander' (go between), which in this sense comes from the name of the character in Chaucer's Troilus and Criseyde. The story is also used by Shakespeare. All these shades of etymological meanings would be lost in translation, if such translation is merely confined to rendering 'go between' or the name. Here too an additional note would be helpful. 
Whether language community considers an object as a source of an ill omen or a good omen is a matter of culture and has its roots in the conventions observed by the society. Social, religious, political and other taboos play an important role in translation. The favourable or unfavourable reaction of the reader /hearer is transferred from the referent to the word. The typical characteristics associated with 'woman' in many cultures include gentleness, 'fair sex' 'kindnesses and even 'sentimentality'. But not all cultures agree about these shades of 'woman'. In some conservative countries a woman is 'حرمة, a characteristic not found in Western societies, where women are fully-emancipated. Thus often reflected connotations differ or even clash where the choices for the translator are limited and suppression or substitution of the referent in the source text is possible, as in

King Richard. The sons of Edward sleep in Abraham's bosom.

(King Richard, IV. 3. 39)

$$
\text { الملك رينشارد. بينما ينام ولدا ادوارد في احضان الموت }
$$

(Translated by Qit, 1968)

The expression 'Abraham's bosom' has a slightly unfavourfable Jewish colouring, or would probably be unfamiliar to the new reader; it is replaced by the usual expression' أحضان الموت which has no unfavourable connotations.

Languages also frequently differ in how they formulate their collocational constructions, which may have different connotations. The translator may feel a certain collocation might evoke unacceptable connotation or might simply be unusual in the target language. Here is an illustrative example;

Pucell. Lo, whilst I waited on my tender lambs,

And to sun's parching heat displayed my cheeks,

God's mother deigned to appear to me.

(King Henry IV, part one, I.2.76-78)

$$
\begin{aligned}
& \text { بوسل. عندما كنت ارعى غنمي } \\
& \text { وحر الثمس يلفح خدي } \\
& \text { تنازلت العذر اء وظهرت لئح }
\end{aligned}
$$

(Translated by Fathi, M., 1959)

The collocation 'God's mother', according to the translator, would be unacceptable to the new reader and is replaced by 'العذر اء' which has the same referent but different connotations. Note also a slight shift in the collocation of 'Father Cardinal' in the Arabic translation in Constance.

And, Father Cardinal, have heard you say

That we shall see and know our friends in heaven....

$$
\text { (King John, î́i.3.76-78) }
$$$$
\text { كونستانس. وقد سمعتك باو الدبي الكاردينال تقور انتا سنرى }
$$$$
\text { ونعرف اصدقاءنا في السماء }
$$

(Translated by Mohammed, M>I.. 1960)

The usual collocation is 'وابونا الكاردينال'; the formal synonym 'والدي' is normally used when the real kinship relation is implied.

Collocations raise a number of questions for translators, which have to be solved before an adequate translation may be achieved. Do a 'red rose' and الوردة' الحماء have the same connotations? Should the original 'collocation is preserved, 'as black as ink' اسود كالحبر' or replaced by a usual collocation in the target language, 'أسود كالقار'. It should be noted here that unusual translation al collocations have been a source of creativeness in languages.

Structural relations linking various lexical items have, as stated above (section 2.5), a power of suggestiveness. The relations may differ from language to language. In English 'gender' evokes 'masculine', 'feminine', and 'neuter' in grammar, and 'male' and 'female ', and 'animate' and 'inanimate' in real life. In Arabic there is no superordinate word for grammatical gender; the relation is confined to masculine and feminine. Again 'family' in Arabic suggests a wide range of kinship relations including grandfather, grandmother, uncle, and aunt, besides father, mother and their children, the three main components of the family in the West. Synonymy which holds between the 'Holy Ghost' and the 'Holy Spirit' is not found in Arabic, where there is only one expression 'روح القد".

Besides, the connotation linking 'Ghost' 'spectre' and 'spook' through polysemy is not evoked by 'حوح' 'حو' 'رو', which may suggest 'مشروب روحي' (alcoholic spirit), suggested by the 'spirit' in English, with further complications connected with the problem of taboo. These associations have to be explained in a footnote.

Any additional meaning suggested by allusions has to be recognized by the translator and brought to the attention of the new reader. For example, we read in King Henry IV, part one (I.3. 56);

Gloucester. Out, tawny coats: Out, scarlet hypocrite: جلوستر. اخسأو ا ياذوي المعاطف المعصفرة ، واخسأ اليها المنافق الاحمر

(Translated by Fahmi, M., 1959)

The allusion here is to the woman in Revelation (VII, 4) 'dressed in purple and scarlet,' In the Arabic Bible the

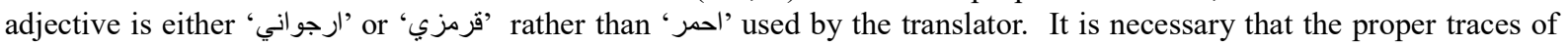
the original allusion be preserved. Here is another example, where the original allusion is lost: 
Porteus. For Orpheus' lute was strung with poets' sinews -

Whose golden touch could soften steel and stones?

Make tigers tame, and huge leviathans,

Forsake uusounded deeps to dance on sands.

(Two Gentlemen of Verona, III. 2. 78-81)

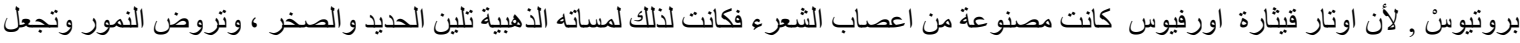

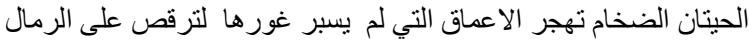

(Translated by Younis, A., 1960)

'Leviathan has a biblical connotation, but in the Arabic Bible one finds ' الحية القديمة 'or 'ايثان'. The allusion in 'Orpheus' lute' is to the mythical Greek musician, singer and poet. A workable knowledge of these allusions is necessary for the new reader to comprehend the text, and for the translator to render them adequately into the target text usually by means of footnotes.

\section{Conclusion}

Connotative meaning has not received enough attention in translation theory although it forms the basis of literature. Six types of connotation are recognized; sound, etymological, referential, collocational, reflected and allusive connotations. Sound connotations are evoked by sound qualities such as alliteration, assonance, rhyme and onomatopoeias. The phonoaesthetic affect of the word may be favourable or unfavourable, as in cacophony found in 'bawza' which conjured up 'ghul' (monster) for the Caliph. In Julius Caesar 'brutish beasts' suggest 'Brutus'. In translation sound symbolism has to be rendered into the new language in one way or another, i.e. through translation or a footnote.

Etymological connotations are suggested by the history of a word. 'Symposium' is derived from Greek, 'drinking party'. The meaning of the word has changed considerably, although it may still retain some of its connotations for those who are familiar with its history. The Arabic word for the tile of Plato's book is 'الو كيمة', which carries some of the original connotations of the world.

Referential connotations, which may be conventional, religious, social, etc are associated with the referent of a word and then transferred to the designation. Taboo words are an obvious example. They differ from culture to culture and require careful attention in translation to avoid giving the wrong message to the new reader.

Collocational connotations are suggested by the frequent use of one word with another: 'night-dark'. Should a colloction be preserved or rendered by a usual collocation into the target language? Should 'as black as ink' be translated as 'اسود كالحبر' or 'اسود كالقار'? It has to be noted that unusual collocations are the source of creativeness in languages.

Reflected connotations are suggested by the structural relations of a vocabulary including synonymy, opposition, hyponymy, homonymy, and polysemy... Puns (son-sun) form the limits of translatability. Other examples of reflected connotations may be less serious, e.g. 'ghost' in English suggests 'spectre' and 'spirit' ; in Arabic 'حوح' may evoke 'نفس ' Here too, if the right equivalent is not found, the translator may have to use a footnote.

Some connotations are the result of intertextuality, one text alluding to another, e.g. 'we are not islands' referring to John Donne's sermon, 'No man is an island '. When the allusion has an established translation in the target language as in the case of holy books, it is normal to quote the established translation, which helps the new reader to recognize the allusion. The discussion in this paper shows that connotative meanings in translation deserve especial attention since they form an essential part of literary texts.

\section{References}

Asphahaani, A. F. (1956). Kitab Al-Ghani. VI. Beirut: Dar Al-Thaqafa.

Hardsley, M. (1975).'Figurative language'. In Anderse, W.B. \&Stagebergb, N (Eds): Introductory Readings on Language. New York: Holt, Rinehart and Winston.

Empson, W. (1953). Seven types of ambiguity. London: Ghatto

Firth, J.K (1957). Papers in linguistics. Oxford: Oxford University Press.

Harvey, B. and Higgins, I. (1992), Thinking translation. London: Routledge.

Hjelmalev, L. (1961). Prologomena to a Theory of Language (translated by Withfield, F.S.). Madison: University of Wisconsin Press.

Lyons, J. (1977). Semantics. Cambridge: Cambridge University Press.

Newark, P. (2011). Non-literary meaning in the light of literary translation. Colchester: Surrey University.

Shakespeare, W. (1975). The complete works of Shakespeare. London: Random House.

Steiner, G. (1975). After Bible. Oxford: Oxford University Press.

Thibault, P.J. (1994). 'Connotation in literature'. In Asher, R.E. and Simpson, J. M.Y. (Eds). The encyclopedia of language and linguistics. Vol. 2/ Oxford: Pergamum Press.

Ullmann, S. (1962). Semantics: An Introduction to the Science of Meaning. Oxford: Blackwell. 